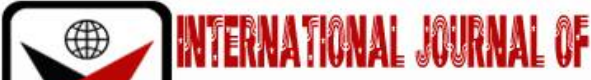

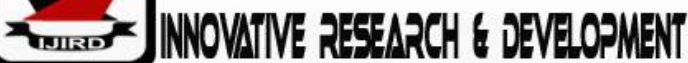

ISSN 2278 - 0211 (Online)

\section{Relationship between Interest to Learn and Secondary School Students' Academic Performance in Kitui County, Kenya}

\begin{tabular}{c} 
Moses M.Mutinda \\
MA Student, Department of Educational Psychology, Kenyatta University, Kenya \\
Dr. Anthony M. Ireri \\
Lecturer, Department of Educational Psychology, Kenyatta University, Kenya \\
Dr. Doyne. K. Mugambi \\
Lecturer, Department of Educational Psychology, Kenyatta University, Kenya \\
\hline
\end{tabular}

\begin{abstract}
:
Kitui County has been consistently posting low performance in Kenya Certificate of Secondary Education from 2012 to 2018. This consistent low performance has brought a need for studies on factors influencing academic performance in the county. This study was done to establish the relationship between interest to learn and academic performance and determining whether there are gender differences in expression of interest to learn among the secondary school students in Kitui County, Kenya. Correlational research design was adopted in this study. The study was based on Vygotsky's sociocultural theory. Random sampling was used to select a sample of 165 form three students to participate in this study. Interest to learn scale which is a sub scale of intrinsic motivation inventory scale authored by Deci and Ryan (2000) was adapted and used to collect data on learners' interest in learning. The end of term examination scores was used as learners' measure of their academic performance. The study was guided by the hypotheses that there is no significant relationship between interest to learn and students' academic performance and that there are no significant gender differences in expression of interest to learn. These hypotheses were tested using Pearson product moment correlation and independent samples $t$-test respectively at 0.05 level of significance. It was found that there is significant positive relationship between interest to learn and students' academic performance $(r=.881, P=.05)$. It was also found that there are significant gender differences in favor of boys for interest to learn. Both hypotheses were rejected. The researcher recommended that teachers should use technology to access resources to enrich learning environments in order to arouse learners' interest in learning.
\end{abstract}

Keywords: Interest to learn, academic performance, gender differences

\section{Introduction}

Many countries across the world value academic performance of the learners and count it as one of the significant indicators of evaluating the quality of education being offered at different levels of education in a country. A study by Oluminde, Olusola and Taofeek (2015) underscored the importance of academic performance among the secondary school students. They assert that the performance of a learner at this level determines the post-secondary institution the learner will join and even the course to pursue in that institution. Most learners who fail at secondary school level may miss opportunities for pursuing various courses which are offered in institutions of higher learning. As Benjamin (2013) points out, failure of learners at secondary school has many far-reaching effects. First, it becomes a source of frustration to the learners. The parents and guardians who commit much of their resources towards education of their children also get frustrated and to some point become desperate when such children fail in academics. Secondly, most sectors of the economy experience inadequacy of skilled manpower consequently causing the overall development of a country to lag behind.

In Kenya, sessional paper no. 1 of 2005 (UNESCO, 2011) states that academic performance is integral part of quality education. This has seen the government of Kenya through the ministry of education and Kenya National Examinations Council employ various mechanisms to ensure integrity and honesty in national examinations such as Kenya certificate of primary education and Kenya certificate of secondary education. These efforts ensure that all candidates post a performance which actually reflects their academic ability. In addition, Kenya universities and colleges central placement service has been using KCSE performance scores as the basis of placing learners in various courses in post-secondary institutions. This is an indication that academic performance in Kenya is a very significant factor which will affect both the learners' academic journey as well as the future career of the learner. The much emphasis on academic performance of the learners has prompted researchers to do studies focusing on various factors which relate to academic performance. Interest in learning is one of the factors whose influence on academic performance has been looked at in a number of 
studies. This variable has been found to influence the performance of the learners at both secondary and university levels of education.

Interest in learning refers to positive reactions by learners towards some learning aspects (Oluminde et al., 2015). Interest in learning is shown through increased engagement of the learner in learning a certain subject. A learner who has interest in learning enjoys pursuing learning tasks and is always ready to pursue hard tasks which may pose challenges to the learner. This implies that a learner who has interest in learning a certain subject may pursue it even if it appears difficult to him and work hard till, he/she performs well in that particular subject. Interested learners are always focused towards achieving success in all academic areas. According to Joe, Kpolovie and Okoto (2014), interest in learning is a major driving force which helps a learner have fast cognitive processing of information and make use of psychomotor traits to work hard and persistently in order to do well at school.

Interest being abroad term may have so many meanings inferred to it. Therefore, it was divided into individual interest and situational interest categories. For the case of this study, interest in learning lies in the category of individual interest. According to Harackiewicz and Hulleman (2010), interest in learning is an innate psychological trait which forms in a learner after exposure to learning tasks. Interest forms from three components namely knowledge, positive emotion and personal values. When learners gain knowledge, they acquire different skills which enhance their level of competency in a given subject. Increased competency leads to development of positive affect which causes the learner to have positive emotions towards that subject. Having positive emotions helps to develop personal value. A learner who has developed personal value sees relevance of a particular subject and sets goals to be achieved in that subject area. Having a combination of the three components results to interest in learning. For example, a secondary school student who realizes that getting a good grade in the overall performance in KCSE will help him/her join a post-secondary institution and pursue a certain course will develop positive emotions towards learning. The learner will then set goals such as the grade to score in the final examination and increase engagement in studies to achieve the set goals. Such a learner will have developed interest in learning. Some research done has established that interest in learning may vary from one task or subject to another or from one learner to another. Interest in learning may also vary from time to time (Saucer, 2012). Lindahi (2007) posit that interest in learning science forms around the age of 13 years and keeps on changing with increasing age of the learner and advancing level of education. However, it was noted that these variations in interest in learning across situations and individuals are difficult to predict.

Research studies have associated interest in learning with improved performance of the learners in academics. Benjamin (2013) reported that increased interest of the learners in learning science resulted to improved performance of the learners in Science subject. Several studies conducted in Nigeria found that interest in learning is a positive correlate of learners' performance in academics (Edem, Ekpenyong \& Martin, 2015; Ezike, 2018; Joe et al. 2014.). These findings were consistent to the findings of Mukhwana (2013) from a study focusing on relationship between interest and learners' performance in Biology among secondary school students in Kenya. The findings of these studies have been corroborated by the findings of studies done in other parts of the world outside African settings. Lawanto, Santoso and Liu (2012) found that engineering students' expectancy for success correlated positively to learners' scores in the interest towards learning scale. Studies that were done in Singapore, Germany and China also reported existence of positive relationship correlation between interest in learning and their scores in academics (Jayanthi, Balakrishnan, Ching, Abdullaatif \& Nasirudeen, 2014; Koller, Baurmert \& Schnabel, 2001; Zheng \& Guo, 2015). The targeted participants in the aforementioned studies were students in secondary school, tertiary institutions and university. Therefore, these studies offer empirical evidence that interest in learning has influence on academic performance of learners at different levels of education.

\section{Statement of the Problem}

The government of Kenya values education and puts efforts towards promoting the academic performance of the leaners especially in public secondary schools. Currently. The government has ensured that all public secondary schools have adequate learning materials and the free secondary education funds which the government funds schools with sustain learners in school to curb absenteeism and other negative factors which would affect the performance of the learners. Despite these efforts, performance in national examinations has remained consistently low nationally with a small percentage of the candidates who sit for KCSE qualifying to join university. In some counties, the performance has been lower than the national mean score for many years. Particularly in Kitui County, KCSE performance was low from 2010 to 2018. The KCSE County mean score for those years is indicated in table 1.

\begin{tabular}{|lrrrrrrl|}
\hline YEAR & 2012 & 2013 & 2014 & 2015 & 2016 & 2017 & 2018 \\
\hline M/SCORE & 4.59 & 5.15 & 5.07 & 5.67 & 4.52 & 4.89 & 5.10 \\
\hline
\end{tabular}

Table 1: KCSE Performance in Kitui County from 2010 to 2016

The consistent low performance in KCSE prompted the researchers to do this study which aims at investigating whether there is a relationship between interest in learning and the students' performance in the county.

\section{Objectives of the Study}

This study was guided by the following objectives:

- To determine whether there is a significant relationship between interest to learn and secondary school students' academic performance. 
- To determine whether there are significant gender differences in expression of interest to learn.

\section{Hypotheses}

The following alternative hypotheses were formulated in relation to the set objectives:

- There is a significant relationship between interest to learn and students' academic performance.

- There are significant gender differences in expression of interest to learn.

\section{Theoretical Framework}

This study was based on sociocultural theory (Vygotsky, 1978). This theory describes how human learning takes place. According to the theory, learning is a social process which occurs as a result of interaction between the learner and an instructor who is much more experienced than the learner. The place where such interaction takes place is referred as cultural context. The cultural context can be at home or school. There are physical and psychological tools which facilitate learning and enable the instructor to effectively pass knowledge to the learner. Such tools include language and facilities and resources within the school. Vygotsky (1978) opined that learning can be gauged as addition of some more knowledge to what the learner already knows. Vygotsky introduced the concept of Zone of Proximal Development which may be defined as the gap between the knowledge which the learner has already acquired and integrated in his or her mental structure and the knowledge which the learner is able to acquire when assisted by others. When new knowledge is acquired, the zone of proximal development extends. The person who assists the learner to acquire more knowledge was referred as the more knowledgeable other. In school context, the teacher is the more knowledgeable other.

According to Christmas, Josiah and Kuzdai (2013), the more knowledgeable other has a responsibility of modelling desired learning tasks which will help scaffold the learner. Scaffolding is a concept which Vygotsky introduced to refer to a process of assisting the learner to advance from a state of not knowing to a point where the learner displays mastery of some ideas and concepts. When the learner shows mastery, the more knowledgeable other dismantles the scaffold.

This theory was found to be appropriate for basing this study because socialization and scaffolding which are some of the main tenets of this theory arouse learners' interest to learn. When the interest to learn is aroused, the learners acquire more knowledge thus extending their zone of proximal development. The extended zone of proximal development leads to improved performance of the learners.

\section{Review of Related Literature}

Research on how interest to learn impacts on academic performance of learners at various levels of education has been done at different parts of the world. The studies which have been conducted at various places have focused on how this variable influences the performance of the learners' overall performance at the end of session examination while others have looked at how interest in learning affects the performance of the learners in a particular subject or course of study.

Eduwem et al. (2017) looked at the impact of interest towards learning on secondary school students' performance in Mathematics. A total of 300 students were sampled from six secondary schools located at Calabar metropolis area of Cross River State in Nigeria. The researchers developed students' psychological variables rating scale and Mathematics achievement test tools for collecting data. This study was done using causal comparative research design. The collected data was analyzed using Pearson correlation and multiple regression analysis. It was found that interest relates positively to learners' performance in Mathematics. Another study that also focused on correlation between interest towards learning and learners' performance in Mathematics targeted 602 grade seven learners studying at Germany (Koller et al. 2001). The learners were tested at three points, that is at the end of grade seven, at the end of the $10^{\text {th }}$ grade and at the end of the $12^{\text {th }}$ grade. At the end of the $10^{\text {th }}$ grade, the learners were to choose between pursuing Basic mathematics or advanced mathematics in the higher grades. The study also aimed at exploring the gender differences in the levels of interest towards learning. Data on mathematics achievement at the three levels was correlated with their interest in learning scores collected at each level. The findings of this study were that there was significant gender difference in favor of boys for both interest in learning and academic achievement. A high percentage of boys that reported to have high interest in learning performed better in Mathematics and chose to pursue advanced mathematics at the higher grades. It was established that interest had no significant relationship with Mathematics achievement in grade seven and grade 10 . However, in the $12^{\text {th }}$ grade, there was significant impact of interest on both academic achievement and choice of whether to pursue Basic or Advanced mathematics course. These finding showed that interest in learning has influence on learners' performance in Mathematics and also impacts on choice in academic related issues. The findings that interest had no significant impact on learners' performance in grade seven and 10 and affecting the same learners' performance at the $12^{\text {th }}$ grade is supported by Saucer (2012) assertion that interest of an individual towards learning can vary from time to time.

In a study to determine whether interest has an effect on learners' performance in Chemistry, Ezike (2018) sampled 208 form two students from 10 secondary schools in Ibadan south west local government area in Oyo State of Nigeria. Data was collected from the participants using Chemistry achievement test and academic interest questionnaire. Data analysis was done and Pearson correlation was used to measure the degree of association between the two variables. It was established that academic interest significantly correlated to learners' scores in Chemistry achievement test. A study conducted in China by Zheng and Guo (2019) explored the relations between academic interest and performance of undergraduate students in medical sciences. A sample of 54398 participants whom 26334 were males and 28064 were females was selected from 87 institutions. Cross sectional research design was used in this study. These 
participants were doing different medical courses such as public health, clinical medicine, basic medicine, Chinese traditional medicine, and preventive medicine. In order to be able to compare effects of academic interest across different disciplines of medicine, the researchers used propensity score matching model. Data analysis showed existence of positive correlation between academic interest and academic performance of the medical students.

Nxumalo (2016) did a study to establish whether interest in learning correlates to academic performance of undergraduate students in Newyork university in U.S.A. The sampled participants were 71 students who volunteered to participate through a Facebook group. These participants were aged between 18 years and 24 years and were composed of 22 males and 49 females. The students submitted their academic performance scores and then completed a modified interest in learning questionnaire online through survey monkey and Facebook websites. Data analysis was done on 54 questionnaires which were found to be useful. Findings indicated that learners' interest in learning related positively to learners' academic performance.

Relationship between interest in learning and performance in Social Studies was studied among college students in Cross River state in Nigeria (Edem et al., 2015). The sample consisted of 753 students drawn from Akamkpa and Obudu colleges. This study adopted ex post facto research design. Data on academic achievement was got from the learners' average scores in Social Studies subject while the researcher developed interest in learning social studies questionnaire to be used to collect data on learners' interest towards learning. The learners' social studies scores were correlated with their interest in learning scores and it was found that interest towards learning correlated positively to learners' average scores in social studies.

A study by Joe et al. (2014) focused on how academic achievement of the secondary school students can be predicted using interest towards learning. This study was done in Bayesla state of Nigeria. The target population were 14 459 students who had enrolled for senior secondary certificate examination in 2013. Random sampling was used to draw a sample of 518 students. Multiple prediction design was used. This study found existence of a significant positive relationship between interest in learning and secondary school students' performance. It was also established that interest in learning can be a significant predictor of the learners' academic performance

A study by Jayanthi et al. (2014) related interest in learning to tertiary institutions' learners' performance in academics. This study was done in Singapore. Convenience sampling was used to select 160 participants. Correlational research design was employed and data was collected using questionnaires. The total number of questionnaires which yielded data for analysis were 144. The sample size of 144 participants consisted of 25 males (17.4\%) and 119 females $(82.6 \%)$. The number of participants who were aged below 20 years were 86 while 58 students were aged above 20 years. In this study, it was hypothesized that there is no significant relationship between interest to learn and academic performance of the students. To test this hypothesis, the outcomes of the completed questionnaire were correlated with the students' average academic performance scores. It was found that there is significant correlation between interest to learn and the learners' performance. Following these findings, the null hypothesis was rejected.

In the Kenyan setting, a study by Mukhwana (2013) explored how interest to learn relates to secondary school students' performance in Biology. A sample of 200 students and 25 biology teachers was drawn randomly from 10 secondary schools in Eldoret municipality. Survey research design was adopted and data was collected using questionnaires and interviews. The collected data was analyzed and Pearson product moment correlation was used to test the hypothesis. It was found that interest in learning correlated positively to learners' performance in Biology. This led to the rejection of the null hypothesis that there is no significant relationship between interest to learn and learners' performance in Biology.

The literature reviewed focused on how interest towards learning influences performance of the learners at different levels of education. Some studies have looked at the influence of the variable on performance in specific subject such as Biology, Chemistry, Social studies and Mathematics. Other studies have explored how interest in learning influence the overall performance of the learners. In all these studies, interest in learning was found to relate positively to learners' performance in academics.

\section{Methods}

This study used correlational research design. The design was selected because the study's aim was to establish the relationship between the existing variables without manipulation of the variables.

\section{Participants}

The sampled participants in this study were 165 form three students drawn from 10 secondary schools located at Tseikuru sub county in Kitui county, Kenya. The sample consisted of 76 males (46.06\%) and 89 females (53.94\%). The age of the participants ranged between 16 years and 23 years. The mean age of males was 18.51 years (S. D=1.52) while the mean age of females was 17.88 years $(S . \mathrm{D}=1.11)$. The overall mean age of the participants was $18.17 y$ years $(\mathrm{S}$. $\mathrm{D}=1.35)$.

\section{Measures}

A questionnaire with two sections was used to collect data from the participants. The first section captured information concerning the learner such as name of the school, category of the school, admission number, age and sex. The second section was interest in learning scale. This scale was an adaptation of a sub scale of intrinsic motivation inventory which was developed by Deci and Ryan (2000) to measure middle school learners' interest in learning. The psychometric properties of intrinsic motivation inventory were tested and verified by Monteiro, Mata and Peixoto (2015) using data from a study done among Portuguese students. This study was done among 3685 students who were in grades ranging from fifth to 12 th grade. Fifth to ninth grade learners were in the primary school cycle while 10 th to $12^{\text {th }}$ 
grade learners were in the secondary school cycle. The sample consisted of 1856 boys (50.4\%) and 1829 girls (49.6\%). The participants' mean age was 13.67 years. Confirmatory factor analysis was done on the data collected using the intrinsic motivation inventory scales. The reliabilities of the sub scales were established through Cronbach alpha and composite reliability scores. The results were that the Cronbach alpha co-efficient of all the sub scales ranged between 82 and .93. Since the alpha values exceed .70, all the subscales were reliable instruments. Thus, it was concluded that interest in learning sub scale is a valid and reliable tool for collecting data among the secondary school students.

\section{Procedure}

In order to confirm the reliability of the adapted tool, piloting of the instrument was done using 20 form three students who were selected randomly from a school which was not included during data collection.

The sampled respondents were issued with questionnaires to complete during the afternoon sessions immediately at the end of the normal class sessions. First, briefing was done and consent of the participants was sought from the respondents. Assurance of confidentiality in handling the research information obtained from the participants was also done. The volunteer participants were given questionnaires to fill within a duration of 30 minutes. The class teachers were requested to assist in administration of the questionnaires. After filling of the questionnaires, they were collected and participants were thanked for their participation. The researcher then collected data on learners' academic performance from the learners' progressive records kept by the class teachers. The academic performance data which was sought are the end of second term 2019 examination average scores. The academic performance scores were standardized to Z-scores to enable comparability of performance from different schools which had administered different examinations. Data coding was done to prepare data for analysis. Pearson product moment correlation was used to determine how interest to learn relates to learners' performance in academics.

\section{Results}

In order to establish the correlation between interest to learn and academic performance, the participants' scores in the interest towards learning scale were correlated with academic performance scores. The results of the correlation are presented in table 2 .

\begin{tabular}{|lcc|}
\hline VARIABLES & Interest to Learn & Academic Performance \\
\hline Interest to learn & 1 & .873 \\
Academic Performance & .873 & 1 \\
\hline
\end{tabular}

Table 2: Relationship between Interest to Learn and Academic Performance Correlation Is Significant at 0.05 Level

The results obtained in this study indicate that there is a strong positive correlation between interest to learn and learners' academic performance. A null hypothesis had been formulated that there is no significant relationship between interest to learn and academic performance. This hypothesis was tested at $\mathrm{P}<.05$ using Pearson product moment correlation. The findings were that interest to learn significantly correlates to learners' academic performance. Therefore, the null hypothesis was rejected. Following rejection of this hypothesis, it was held that interest to learn is a significant and positive correlate of secondary school students' performance in academics.

The second objective of this study was to test whether there are significant gender differences in expression of interest to learn. In line with this objective, a null hypothesis was formulated that there are no significant gender differences in expression of interest to learn. independent samples t-test was conducted to test this hypothesis and yielded the statistics presented in table 3 and table 4 .

\begin{tabular}{|c|c|c|c|c|c|}
\hline & GENDER & $\mathbf{N}$ & Mean & $\begin{array}{c}\text { Std. } \\
\text { Deviation }\end{array}$ & $\begin{array}{c}\text { Std. Error } \\
\text { Mean }\end{array}$ \\
\hline \multirow{2}{*}{ INTERESTTOLEARN } & MALE & 76 & 3.3795 & .51457 & .05903 \\
\cline { 2 - 6 } & FEMALE & 89 & 3.1983 & .47758 & .05062 \\
\hline
\end{tabular}

Table 3: Group Statistics 


\begin{tabular}{|c|c|c|c|c|c|c|c|c|c|c|}
\hline & \multicolumn{3}{|c|}{$\begin{array}{c}\text { Levene's Test for } \\
\text { Equality of Variances }\end{array}$} & \multicolumn{7}{|c|}{ t-test for Equality of Means } \\
\hline & \multirow{2}{*}{\multicolumn{2}{|c|}{$F$}} & \multirow[t]{2}{*}{ Sig. } & \multirow[t]{2}{*}{$\mathrm{t}$} & \multirow[t]{2}{*}{$\mathrm{df}$} & \multirow[t]{2}{*}{$\begin{array}{l}\text { Sig. (2- } \\
\text { tailed) }\end{array}$} & \multirow[t]{2}{*}{$\begin{array}{c}\text { Mean } \\
\text { Difference }\end{array}$} & \multirow[t]{2}{*}{$\begin{array}{l}\text { Std. Error } \\
\text { Difference }\end{array}$} & \multicolumn{2}{|c|}{$\begin{array}{l}\text { 95\% Confidence } \\
\text { Interval of the } \\
\text { Difference }\end{array}$} \\
\hline & & & & & & & & & Lower & Upper \\
\hline \multirow[t]{2}{*}{ INTERESTTOLEARN } & $\begin{array}{c}\text { Equal } \\
\text { variances } \\
\text { assumed } \\
\end{array}$ & 0.054 & 0.817 & 2.34 & 163 & 0.02 & 0.18116 & 0.0773 & 0.02851 & 0.333 \\
\hline & $\begin{array}{c}\text { Equal } \\
\text { variances } \\
\text { not } \\
\text { assumed }\end{array}$ & & & 2.33 & 154.61 & 0.021 & 0.18116 & 0.07776 & 0.02755 & 0.334 \\
\hline
\end{tabular}

Table 4: Independent Samples t-test

The statistics presented in table 3 and table 4 indicate that there were significant gender differences in favour of boys for interest to learn. The hypothesized relationship was not supported. It was held that there are significant gender differences in expression of interest to learn.

\section{Discussion}

The findings of this study have indicated that interest in learning significantly and positively relates to learners' academic performance. This implies that increased interest in learning would translate to improved performance of the learners in academics.

The findings of this study were in line with the findings of the previous studies which looked at the relationship between interest to learn and learners' performance in academics. These include two studies done in U.S.A among secondary school students and university students (Lawanto et al., 2012; Nxumalo, 2016). Studies that were done in Nigeria to establish relationship between interest in learning and performance in subjects such as Social studies, Chemistry and Mathematics corroborated the findings of the current study (Edem et al., 2015; Ezike, 2018; Eduwem et al., 2017). These studies reported existence of a positive relationship between learners' scores in interest towards learning scale and their scores in the stated subjects. In addition, in his study of two participants' performance in reading and writing English. Saucer (2012) established that the learners' interest in reading or writing determined how the learners performed in those learning tasks.

In a study conducted among Chinese medical students, it was reported that the students' interest in learning related positively to the learners' performance in different medical courses (Zheng \& Guo, 2019). The positive correlation of the variables in this study may be attributed to the fact that the learners who have already specialized in a particular medical course may have done so on basis of being interested in that particular course. Koller (2001) posit that interest plays a major role in choosing a course to pursue and when a course is chosen out of interest, this is a major factor that may lead to good performance of a learner in that particular course. It's imperative that if learners chose the different medical courses while driven by interest, then interest may have impacted positively on their performance in those courses. the findings that there are significant gender differences in terms of interest to learn are in line with the findings of a study done by Koller et. al., (2001) among learners in different grades in Germany. The two studies had similar findings that there were significant gender differences in expression of interest to learn and the differences are in favour of boys.

However, there were inconsistencies in research whereby some studies had contrary findings. Benjamin (2013) studied interest in learning as a correlate of the learners' performance in sciences. The targeted participants were 35 form three students from one co-educational secondary school. This study employed quasi experimental research design and embedded qualitative design of action research. The findings of this study were that there were no significant differences in performance between the learners in the experimental group and those who were in the control group. This was an indication that interest in learning science had no significant impact on learners' performance in science.

\section{Conclusions}

This study has established that interest in learning correlates positively and significantly to secondary school students' overall performance in academics. This is in line with the findings of the majority of the studies which have been looked at on the correlation between the two variables. Therefore, it is concluded that learners' interest towards learning should be emphasized as an important factor that should be considered in regard to promoting the academic performance of the learners.

From the findings of this study, it was established that boys express more interest towards learning compared to girls. This implies that interest to learn is likely to have more impact towards performance of boys as compared to girls.

\section{Recommendations}

Teachers are noted as significant role players in arousing the interest of the learners towards learning. Teachers should enrich the learning environments with resources and give learners more room for active engagement and enjoyment of learning tasks. The teachers should design lessons and present them in ways which are interesting to the 
learners. For example, by utilization of technology, a teacher can access and use teaching aids such as videos, pictures and animations. All these efforts arouse the interest of the learners towards learning that particular subject. Aroused interest of the learners in different subjects will result to improvement in overall performance of the learners.

Since empirical evidence has shown that girls express less interest towards learning as compared to boys, its recommended that teachers should increase attention towards girls during the teaching sessions to ensure that they arouse the girls' interest towards learning.

\section{References}

i. Benjamin, A. (2013). The impact of performance assessment on students' interest and academic performance in science. (Unpublished Masters Thesis). University of West Indies. Retrieved from www.uwi.edu. Date accessed: $18^{\text {th }}$ December 2019.

ii. Christmas, D., Josiah, M., \& Kuzdai, C. (2013). Vygotsky's Zone of proximal development theory: What are the implications for mathematical teaching? Greener Journal of Social Sciences, 3(7), 371-377.

iii. Deci, E.L., \& Ryan, R.M. (2000). Self-determination theory and the facilitation of intrinsic motivation, social development and wellbeing. American Psychologist, 55, 68-78.

iv. Edem, A.E., Ekpenyong, E.E., \& Martin, O.I. (2015). Students' interest in social studies and academic achievement in tertiary institutions in cross river state Nigeria. European Journal of Training and Development Studies, 2(2), 35-40.

v. Eduwem, J.D., Umoiyang, I.E, \& Otu, B.D (2017). Psychological factors and secondary school students' academic performance in mathematics. Journal of research and method in education. 7(2). 6-13. www.iosrjournals.org.

vi. Ezike, B.U. (2018). Classroom environment and academic interest as correlates of achievement in secondary school chemistry in Ibadan south local government area, Oyo state, Nigeria. Global journal of educational research, 17, 61-71. DOI: https://dx. Doi.org/10.4314/gjedr. v17:1.9.

vii. Harackiewicz, J.M., \& Hulleman, C.S. (2010). The importance of interest: The role of achievement goals and task values in promoting the development of interest. Social and personality psychology compass. 4(1)42-52. DOI: 10.1111/j.1751-9004.2009. 00207.x

viii. Jayanthi, S.V., Balakrishnan, S., Ching, A.L., Abdullaatif, N.A. \& Nasirudeen, A.M. (2014). Factors contributing to academic performance of students in a tertiary institution in Singapore. American journal of educational research. 2(9). 752-758.

ix. Joe, A.J., Kpolovie, P.J., \& Okoto, T. (2014). Academic achievement prediction: Role of interest in learning and attitude towards school. International journal of humanities, social sciences and education, 1(11), 73-100.

x. Koller, O., Baumert, J. \& Schnabel, K. (2001). Does interest matter? The relationship between academic interest and achievement in mathematics. Journal of Research in Mathematics Education. 32 (5). 448-470. DOI: $10.2307 / 749801$.

xi. Lawanto, O., Santoso, H.B., \& Liu, Y. (2012). Understanding the relationship between interest and expectancy for success in engineering design activity in grades nine to twelve. Educational Technology and Society. 15(1). 152161.

xii. Lindahi, B. (2007). A longitudinal study of students' attitude towards science and choice of career. Paper presented at the 80th NARST International conference. New Orleans, Louisiana.

xiii. Mata, L.M., Monteiro, V., \& Peixoto, F. (2015). Intrinsic Motivation Inventory: Psychometric properties in the context of first language and mathematics learning. Psychology, 28(3), 434-443.

xiv. Mukhwana, W.J. (2013). The role of student related factors in the performance of Biology subject in secondary schools in Eldoret municipality. Journal of Emerging Trends in Educational Research and Policy Studies, 4(1), 64-73.

xv. Nxumalo, M.W. (2016). Relationships between reading ability, vocabulary, reading attitudes and academic performance among form five learners in Swaziland's public schools. Retrieved from: http://hdl.handle.net/10500/22187.

xvi. Oluminde, O., Olusola, O., \& Taofeek, S. (2015). Parents and students' interest as determinants of students' academic performance in agricultural science in selected secondary schools in Oyo state, Nigeria. International Journal of Academic Research in Progressive Education and Development, 4(4), 11-20.

xvii. Saucer, K. (2012). The impact of student interest and instructor effectiveness on student performance. Research paper. Retrieved from: http://fisherpub.sjfc.edu/education-ETD-masters.

xviii. United Nations Educational, Scientific and Cultural Organization, (UNESCO). (2011). Education for all: Global monitoring report. Paris, France: Author.

xix. Zheng, H.J. \& Guo, J. (2019). Does academic interest play a more important role in medical sciences than in other disciplines? A nationwide cross-sectional study in China. Retrieved from www.boimedcentral.com

xx. Vygotsky, L.S. (1978). Mind in Society: The development of higher psychological- processes. In M. Cole, V. JohnSteiner, S. Scribner, \& E. Souberman (eds.), Cambridge, MA: Harvard University press. 


\section{Appendix}

Section A: Instructions and Background Information

This questionnaire is not an examination and it is meant to collect data to be used for the research purposes only. There are no right and wrong answers. The data collected with this questionnaire will be treated with utmost confidentiality. Please complete the entire questionnaire to the best of your knowledge.

The time set to complete this questionnaire is 30 minutes.

Background Information

Name of school

Category of the school

$\begin{array}{ll}\text { Girls only boarding } & (\text { ) } \\ \text { Mixed boarding } & (\text { ) } \\ \text { Mixed day school } & (\text { ) }\end{array}$

Admission Number

Age

Gender

Section B: Interest to Learn Scale

For each of the following statements, tick the response which mostly reflects your behavior

\begin{tabular}{|l|l|l|l|l|l|}
\hline & $\begin{array}{c}\text { Very untrue } \\
\text { of me }\end{array}$ & $\begin{array}{c}\text { Untrue } \\
\text { of me }\end{array}$ & $\begin{array}{c}\text { Somewhat } \\
\text { untrue of me }\end{array}$ & $\begin{array}{c}\text { Neutral } \\
\text { True of } \\
\text { me }\end{array}$ & $\begin{array}{c}\text { Very true } \\
\text { of me }\end{array}$ \\
\hline 1. I enjoy learning very much & & & & & \\
\hline $\begin{array}{l}\text { 2.Learning is fun to me think learning is a boring } \\
\text { activity }\end{array}$ & & & & & \\
\hline $\begin{array}{l}\text { 4. I can describe learning as a } \\
\text { very interesting activity }\end{array}$ & & & & & \\
\hline $\begin{array}{l}\text { 5. I think learning is a quite } \\
\text { enjoyable activity }\end{array}$ & & & & & \\
\hline 6. I do not enjoy learning & & & & & \\
\hline $\begin{array}{l}\text { 7. Learning activities do not hold } \\
\text { my attention at all }\end{array}$ & & & & & \\
\hline
\end{tabular}

Table 5 